\title{
Power, National Unity, and Territorial Integrity: the Cases of Russia's Chechnya and Ukraine's Crimea
}

\author{
Ali Askerov, PhD \\ Thomas Matyok, PhD \\ http: //hhs. uncg. edu/wordpress/cps/ \\ http: //hhs. uncg. edu/wordpress/cps/academics/ \\ 210 Mclver Building, UNCG, PO Box 26170 \\ Greensboro, NC 27402-6170, 336. 334. 4781 \\ abaskaro@uncg.edu, tgmatyok@uncg.edu
}

Abstract

Perhaps, in the age of globalization, the concepts of national unity and territorial integrity sound to many of us like obsolete terms, although they are still important to international law. But, no matter whether they remain essential or worthless they are equally applicable to both Russia and Ukraine. This paper discusses Russia's stern approach to strangle the freedom aspirations in Chechnya to preserve its own territorial integrity, while avidly pushing Crimean Russians to separating from Ukraine thereby ruining its national unity. While the political scientists talk about an increasingly integrated contemporary world in which the concept of power loses its classical meaning, Russia's brute force-based aggressive policies towards Ukraine refute the arguments that traditional state forms have disappeared. The cases of Crimea and Chechnya have many similarities, however Russia's approach to them has been very different.

Keywords: Russia, Ukraine, Crimea, Chechnya, power, territory, unity

\section{Introduction}

Perhaps, the most remarkable event of the 1990s in the post-Soviet Russia is the Chechen war of liberation that started in December 1994 and lasted until August 1996. The war seemingly ended with the signing of the Khasavyurt Accord resulting in a truce among the combatants. The Kremlin portrayed this war as illegitimate and presented it as violating the rules of international law, such as territorial integrity and national unity. Moscow portrayed the Chechen rebels as bandits and terrorists who targeted Russia's unity, peace, and economic prosperity. Thus, the Kremlin worked hard to make it known that restoring the disturbed peace and order in Chechnya, a breakaway republic of the Russian Federation, through the application of brute force, was ethical and legitimate. Nonetheless, after two-years of devastating combat, Russia lost the war and was forced to sign the Khasavyurt ceasefire agreement in August 1996, and the Moscow Treaty in May 1997 that forbade the use of force to resolve further differences between Russia and Chechnya, as well as deferring the determination of the final status of Chechnya to 2001. By then, Chechnya would exist as a de-facto independent state and prepare all necessary infrastructure for full independence. Regardless of the agreements made, the war resumed in August 1999 under controversial conditions creating an opening for the Kremlin to restore Russia's authority in Chechnya. This phase of the conflict is called the Second Chechen War that still continues, today. In contrast, the Kremlin and the pro-Russian Chechen authorities in Grozny continue to claim that the Second Chechen War was over in April 2009.

In early 2014, almost 20 years after the start of the First Chechen War, Russia invaded the Crimean peninsula, an integral part of Ukraine. The events in Crimea, resulting in Russia's annexation of the peninsula, have revealed Russia's longexisting, but hidden, expansion agenda. The Kremlin's hard-hitting policy choices vis-à-vis the former Soviet regions included options such as the creation and perpetuation of conflict, invasion, recognition, and annexation to satisfy its interests and perpetuate its influence in the region's affairs. Russia's unfriendly approach to Ukraine has a long history, and the forced annexation of an integral part of a sovereign nation has had a shocking effect on people and governments worldwide. Despite the imposition of western sanctions, Moscow continued its brutal policies and moved forward to 
encourage secessionism in the eastern part of Ukraine, where violent conflict erupted between the Kremlin-backed local Russian separatists and Ukrainians.

As Russia continues to engage in power politics, it appears that it looks anywhere for justification of its brutality. For Russia, it is a matter of presenting myriad explanations for its actions and following the one that the community of nations is most willing to accept. This appears the case following Russia's suggestion that its interests in eastern Ukraine are in protecting ethnic Russians. The Kremlin articulated Russia's presence as an outcome of its responsibility to protect. With an eye to the Balkans, Russia responded to international criticism of its intervention in Ukraine by pointing to the west's use of responsibility to protect in Kosovo.

This paper analyzes the power-oriented aggressive policy choices of Russia in its historical "backyard"- Chechnya- and its antagonistic policy toward Ukraine. Our goal in this paper is to recognize how Russia's contemporary power-driven aggressive policies towards its neighbors are framing Russia's current and future standing as a regional and global power. The common points regarding these two separate, though complimentary, cases are related to national unity and territorial integrity of a nation-state. Russia has participated in both conflicts where its positions are controversial. Interestingly, in these two different cases, despite being in opposite positions, Russia has been able to posture itself favorably. In the case of Chechnya, Russia justified its position with the right to protect its national unity and territorial integrity suppressing Chechens' aspirations for self-determination, while in the case of Crimea fully supporting the Crimean Russians' separation from Ukraine to join Russia. These two cases are a sign of the futility of international law to achieve justice; rather they show that power, a realist concept, still plays a decisive role in Russia-centered politics.

The application of pure power politics allows Russia to craft explanations after its actions. Without any necessity to build democratic consensus, it is free to act solely because it has the power to do so. An explanation of the action is an afterthought for the history books, something for scholars to debate while mapmakers engage in redrawing the world.

\section{Russia's Chechnya}

The Chechen question for Russia has more than a 300-year-old history. Imperial Russia passed the Chechen problem to Soviet Russia in the late 1910s and, in turn, it handed the issue to an independent Russia in 1991. Throughout this period, Chechens, together with other mountaineers of the North Caucasus, fought against Russian troops either to preserve their freedom or to gain their independence. At various times and for many reasons, one of the biggest issues for Russia has been the Chechen problem. It has been hard to subdue these people because of their nature and the unique geographical characteristics of the region. As a result of their pressure against Russia for a free and independent state, Russia has felt it necessary to deploy large troops in the region, at a very high cost.

In the $19^{\text {th }}$ century, there had been three important resistance movements in the North Caucasus that Imperial Russia was not able to entirely subdue (Gammer, 2006). The Chechens continued to challenge and resist the political order in the Soviet times as well. The Chechen secret movement for independence took place under Hasan Israilov, which contributed to the Kremlin's decision to exile Chechens to Siberia and Kazakhstan in 1944. This national tragedy did not curb the Chechens' desire for freedom and independence and they were repatriated to their homeland in 1957 by a decree issued by Nikita Khrushchev, then first secretary of the Central Committee of the Communist Party of the Soviet Union. Having returned home the Chechens did not find everything as they had left it; others that moved to the region from other parts of the Soviet Union occupied their homes and contributed to the dissolution of Chechen identity grounded to a geographic space (Askerov, 2011). But these problems were gradually resolved. The political status of Chechnya as an autonomous republic within the Russian Federation was returned. When the Soviet Union collapsed in 1991, and all fifteen constituent republics of the Soviet Union became independent, Chechnya started to prepare the necessary conditions to declare its independence from Russia as well. This was materialized in late 1991 under Johar Dudayev's leadership.

The Kremlin, naturally, had made a great effort to preserve Russia's integrity. First, the Kremlin organized a Chechen opposition under the leadership of Ruslan Labazanov and Beslan Gantemirov that received significant material support from Moscow, against the Chechen rebel government. Moscow also supported the political opposition of Umar Avtorkhanov to Dudayev. But, none of these was successful in toppling Dudayev's government by force (Seely, 2001). Recognizing the stakes involved, and in an attempt to hold Chechnya firmly in its orbit, in late 1994 the Kremlin dispatched federal troops to Grozny initiating the First Chechen War. 
The war lasted until August 1996 concluding with the sides signing the Khasavyurt Peace Accord, which legally ended the conflict. The stipulations of the accord were quite unfavorable for Russia. In 1997, the sides signed the Moscow Treaty, which enclosed a provision that the sides would not resort to force to resolve their differences whatsoever and to negotiate the ultimate status of Chechnya in 2001. This was interpreted as a victory for Chechnya even though its final status was postponed until 2001. The Kremlin, however, did not wait until the proposed date to resolve Chechnya's final status and it renewed the war in August 1999 after gaining the strength necessary to change the situation in its own favor.

The latter phase of the Chechen conflict is associated with the name of Vladimir Putin who played a key role in formulating and implementing Russia's new Chechen policy. President Yeltsin surprisingly appointed him as prime minister on August 9, 1999 and the Second Chechen War started on August 26, 1999. On December 31, 2000, Putin became an acting president of Russia following the resignation of President Yeltsin.

With Putin in charge, Russia's war strategy changed dramatically. The Kremlin developed new policies that involved increasingly greater use of brutal force in Chechnya, ignoring the war's impact on civilian lives, and quelling the free media blocking an unrestricted and objective information flow from the region to the rest of the world (Gilligan, 2010). Arguably, the first official step to strengthen the state's administrative influence on the mass media was Russia's Security Council's adoption of 'Information Security Doctrine of the Russian Federation' approved by President Vladimir Putin on September 9,2000 . The doctrine represented the state's official policy regarding information security in Russia, which had increased the Kremlin's capacity to shape the role the media played in reporting from the North Caucasus. Embattled in war, the narrative that flowed out of the North Caucasus was framed by Russia leaving Chechen voices silenced.

The State Duma in June 2002 adopted another law called 'On Counteraction of Extremist Activities'. The new law further limited the role of a free media by prohibiting the "dissemination of extremist materials via the mass media and the conduct of extremist activities by the mass media" (Soldner, 2008: 169). These legal restrictions adversely affected the free media in Russia- one of the most significant signs of democracy in any country- and were supported by an implied connection to the war on terror and a need to protect the state. The Kremlin considered terrorism as equivalent to the Russian war in Chechnya, and consequently, these documents targeted Chechnya rather than any other part of the Russian Federation.

Moscow's policy to curb insurgency at any cost led to an increase in civilian casualties in Chechnya in the early 2000s. Estimates show that every fourth resident of Chechnya passed through the new filtration centers system in Chechnya used by the Russian troops to beat, torture, and even execute detainees. According to Memorial, a Russian civil rights society, the purpose of the filtration system in Chechnya was to create a network of informers through forced recruitment. The system was part of the general state terror policy of suppression and intimidation of an entire population and was characterized by its arbitrary arrests and mass detentions of innocent people (Gilligan, 2010).

Ultimately, the Kremlin has been successful in preserving Russia's territorial integrity through the use of brute force in Chechnya. The cost of this has been heavy for civilians, as well as democracy in Russia. The free media and journalists have suffered tremendously from oppressive official Russian policies as well. Civilian casualties in Chechnya are estimated at up to 250,000. Russia has lost about 40,000 troops in Chechnya during the conduct of both wars. Rebel casualties are approximately the same. The number of internally displaced persons, and refugees from Chechnya due to the war, along with defections, has also been huge (Nichols, 2000).

\section{Ukraine's Crimea}

Following independence from the Soviet Union in 1991, Ukraine, like all the other former Soviet republics, had to decide which political orientation to adopt. Located in Eastern Europe, it had to select one of two major approaches to governance: pro-Western or pro-Russian. Despite some hesitations, Ukraine's initial orientation was pro-Russian which lasted until the Orange Revolution that resulted in Viktor Yushchenko rising to power in 2005. Up to this time, Kiev had not been able to introduce serious economic and military strategies to achieve significant welfare and security reforms (Ulrich, 2007). As a result, Ukraine remained linked to Russia for economic and security reasons. Yushchenko's government did not want, however, to see Ukraine continue as a satellite state of Russia in the long term. Kiev's new pro-Western liberal policies and leanings displeased the Kremlin and it became the source of significant tensions between the previously allied countries. Arguably, however, the history of Russia's massive covert involvement in Ukraine's affairs has had even deeper roots (Wilson, 
Most Ukrainians perceived Russia as the major source of their troubles, and as a consequence Ukrainians were receptive to movements that would shift their country away from Russia and to integration with Europe. This desire for integration into the European family of nations caused an overwhelming social mobilization in Ukraine. In November 2004, hundreds of thousands of Ukrainians rallied in Kiev to protest the authoritarianism of Ukraine and Russia's role in keeping it alive in the country. At the heart of the protests were the people's demand for free and fair elections and justice (D'Anieri, 2010).

Even under Soviet rule, many Ukrainians accused Russia of developing too severe policies for implementation in Ukraine. 1 In the 1920s and 1930s, hundreds of thousands fled Ukraine due to Soviet land policies. Many Ukrainians developed a sense that they were relatively deprived in the Soviet Union and that Russia had stifled their language. Russia suppressed Ukrainian identity and replaced it with a Russian identity on behalf of the existing pro-Russian national projects (Plokhy, 2006). Ukraine was seen as the breadbasket of the Soviet Union, and while not being as politically effective as Russia, its agricultural strength provided it with a strategic worth that could not be dismissed. Memories about the deadly famine in the country have been alive and transformed for new generations helping to develop deeper grievances about the communist regime and its policies. Most Ukrainians ceased to see Russians as their brethren, despite a large Russian population in the country. This was manifested during the Orange Revolution that brought Yushchenko to power to build a new Ukraine outside of Russian-led political and economic domains.

The political circumstances in the mid-2000s in Ukraine were not in favor of Russia. Analysts argued that regardless of who became Ukraine's president, the conditions would not improve (Pastukhov, 2006). After Yushchenko's presidential term ended in 2010, new developments in Ukraine did not go in accordance with Russia's plans pushing it in search of new projects that appeared to be supporting and empowering of the pro-Russian forces in Ukraine. Yushchenko's ineffective economic policies coupled with the slow integration process of Ukraine with Europe were exacerbated by the misfortunate global economic crisis that hit the country hard (Schuerkens, 2012). Unfulfilled and rising expectations of the people of Ukraine facilitated Viktor Yanukovich's coming to power in 2010.

Yanukovich was not sympathetic to the pending Ukraine-European Union Association Agreement; rather, he chose to pursue a policy of strengthening ties with Russia. He preferred to obtain a Russian loan bailout to address immediate economic needs of the country rather than address the necessity for long-term economic reforms. This policy angered proWestern Ukrainians who started mass protests against the government in Kiev. In early 2014, events escalated into deadly clashes across the country between police units and citizens. On February 22, 2014, President Yanukovich fled Kiev for Kharkiv, then Crimea, and finally onto Russia.

Russia's reactions to events in Ukraine were twofold. First, the Kremlin tried to alleviate the problem in Ukraine through economic incentives offered to Kiev. But Moscow gradually galvanized its approach to events in Ukraine as they raised and nurtured anti-Russian sentiments. Russia's inability to preserve the Yanukovich government against the revolution in Kiev manifested itself in the form of a political crisis in Crimea.

\section{1 Crimea: History, Law, Politics}

At one point, the Crimean Khanate was a nightmare for Imperial Russia. The Crimean Tatars were even able to conquer Moscow in 1571 when they burned the entire city, excluding the Kremlin. The raids of the Tatars of the Crimean Khanate on the territories of the southern Russia started in the early $16^{\text {th }}$ century and continued until the late $17^{\text {th }}$ century. The Crimean Tatars were almost always supported by a third power. Nonetheless, their presence had created a serious problem for Russia's security and economic growth. Russia under Catherine the Great managed to conquer the peninsula in 1783 and it remained as part of Russia until 1954 despite the change in the political structure of the country.

There were two short intervals between 1783 and 1954 that the Russian state did not control the region. Those intervals were associated with the civil war started after the demise of the Tsarist Russia in 1917 and the Nazi invasion of the peninsula in 1942. The Crimean Tatars were exiled in 1944 after the peninsula was liberated from the Nazi troops for their

\footnotetext{
1 One of the authors of this paper witnessed a number of such cases in Kiev in 1988. His young Ukrainian friends had talked about the disaster of Chernobyl as sadly as the famine of the 1930s that happened long time before they were born. They held Russia as responsible as Joseph Stalin, the Soviet leader of the time.
} 
alleged cooperation with the Germans. About 250,000 Tatars were deported to Uzbekistan and Kazakhstan and were never allowed to return to Crimea until the 1980s.

In 1954, Crimea was transferred to Ukraine, which was a constituent part of the Soviet Union. Nikita Khrushchev, general secretary of the Communist Party, played a key role in this transfer. Crimea remained as an integral part of Ukraine following its independence with the collapse of the Soviet Union in 1991. In February 2014, a crisis between Russia and Ukraine erupted on the peninsula.

Obviously, Crimea's history is quite complex, and by no means interpretations of recent events anchored to the historical past result in Russia's favor (Magocsi, 2014). At the very least, the peninsula belonged to someone else, as explained above, before and after it was part of Russia from 1783 to 1954. If entitlements based on history were legally valid, others' claims for Crimea would be stronger than Russia's. Indeed, the principle of uti possidetis in international law makes Ukraine's position stronger than Russia's. Having its roots in the Roman law, the principle originates from Latin America's practice of decolonization meaning that a newly independent state retains the borders it had as an administrative entity of the disintegrating state (Lalonde, 2002; McWhinney, 2007). This well established rule of international law refutes Russia's claims to the right over the peninsula based on Crimea's attachment to Ukraine in 1954. If Russia's claims formed a precedent for the former Soviet republics, the political map of the post-Soviet region would sharply change.

Russia's covert support for the demonstrations in the peninsula against Kiev in early 2014 gradually took on an open character. Russia's intervention culminated in capturing the legislative and government buildings in Crimea and Sevastopol, a city on the peninsula with a special status, in late February 2014. The dissolution of the Council of Ministers of Crimea was followed by the declaration of a new prime minister of the autonomous region. Sergei Aksyonov, the leader of the Russian Unity party and a declared prime minister, cooperated with the Kremlin to quickly isolate the peninsula from Ukraine through Russian military campaigns in Crimea.

Russia has tried to justify Crimea's annexation with a number of factors ranging from the will of the majority of the population of the peninsula, historical elements, and preserving the rights of Russian compatriots, among others. Paradoxically, Russia's current and recent history is full of cases having considerable similarities with the case of Crimea. Tatarstan, Chechnya, and Tuva, the republics of the Russian Federation with their own aspirations for independence, to name just a few, would go free if Russia sincerely respected the values and rights it claimed to protect for the Russian population of Crimea (Amirkhanov, 1998; Drobizheva, et al. , 1998; Toler, 2010).

Self-determination of the Russian population of Crimea at the expense of the rights of other ethno-cultural groups living in the peninsula would somehow be understood, if the region became independent without joining Russia. The political developments in Crimea supported by legal means grew in a way to legitimize Russia's invasion of the region. The Kremlin denied the demands of the non-Russian population of Crimea against joining Russia ignoring their political and national existence. Moscow disdained the Tatar population of the peninsula ignoring their political aspirations, and cultural and identity needs.

Crimean Tatars, the indigenous peoples of the peninsula, have been against Crimea's unification with Russia, despite Vladimir Putin's promises to grant them greater autonomy with special privileges within the Russian Federation. Among other factors, Tatars' stance has been shaped by Moscow's severe policies towards them during different political epochs. They were exiled en masse in 1944 to Siberia, Central Asia, and Kazakhstan, and were allowed to come back to Crimea only in the late 1980s (Sheehy \& Nahaylo, 1980; Uehling, 2004). Just to compare the Tartars' situation with the case of the Chechens, for example, who were exiled at the same time but were allowed to repatriate in 1957, makes the Tatars' pains more understandable. They had faced too many exiles throughout Russian rule, therefore when asked to narrate exile, they need clarification about which one (Uehling, 2004). The returning Tatars have faced not only material hardships in their own lands, but also severe discrimination. In late March 2014, the Crimean Tatars representative body, Kurultay, gathered to evaluate the political situation in the peninsula and decide about the fate of the Tatars. But it ended without reaching any tangible decision.

Crimean Tatars, making up slightly more than 12 percent of the Crimean population, were important for the Kremlin to further justify its annexation policy. Even in 1991, Tatar leadership received an offer from President Boris Yeltsin to join Russia in return for being granted the status of Crimean Tatar national autonomy (Shevel, 2014). The Tatars rejected the Kremlin's offer in 1991 just as they did in March 2014 unequivocally choosing Ukraine. They rallied against Russia but their 
nonviolent resistance did not play a significant role in stopping the peninsula's invasion. The Kremlin has been in a continuous effort to build a new nation in Russia throughout the independence period (Shevel, 2011). The Crimean events have indicated that the process of nation building in Russia is not complete yet.

Ironically, not all Crimean Tatars enjoyed equal rights with the Ukrainian citizens, since Kiev did not extend the right of automatic Ukrainian citizenship to Crimean Tatars. The Ukrainian parliament recognized Crimean Tatars as indigenous peoples of Crimea only after Russia's annexation of the peninsula (Goble, 2014). Crimean Tatars had hoped that their own system of self-administration, although the Ukrainian government never recognized it, would become a national government some time later. Despite the Kremlin's promises of higher autonomy for Crimean Tatars, they have been facing increasing political pressures on a daily basis in the peninsula after Russia's annexation (Izmirli, 2014).

\section{Discussions and Conclusions}

The cases of Russia's Chechnya and Ukraine's Crimea are idiosyncratic but also they have many similarities. The first and most important parallel is related to a sovereign struggle to preserve one's own territorial integrity. The sovereigns, Russia and Ukraine, have a legitimate right under international law to protect their territorial integrity and national unity. Nonetheless, the odd fact is that Russia, suffered tremendously due to the wars in Chechnya, had itself disturbed Ukraine's national unity and territorial integrity. Russia has been a party to both the Chechen and Crimean crises, in which it is in different and opposing positions. Russia's approach has instigated wonders and questions, since the same state cannot be right in two opposite situations of the similar cases.

Russia has tried to justify its Crimean policy through referendum, even though it was held under force and Crimean parliament's request about reunification with Russia, ignoring the national parliament in Kiev. It is no secret that the Kremlin put this scenario into life to justify its power politics. However, the Kremlin did not respect the true popular elections in Chechnya such as the 1991 referendum that confirmed Johar Dudayev as President of the Chechen Republic of Ichkeria and the declaration of Chechnya's independence. Russia had made a number of attempts to terminate the elected proindependence Chechen government forcefully. The Kremlin chose to go to war when Moscow was not successful in destroying a free and self-governing Chechen government in Grozny. With the onset of the Second Chechen War in 1999, Russia eagerly went to war to restore its unity without caring about civilian casualties, devastating cities and towns, and dying Russian soldiers. The Kremlin had tried to justify its use of force by its rights to restore the constitutional order, national unity, and territorial integrity.

Russia's use of power politics has not stopped in Crimea. While the events in the peninsula were hot, the Kremlin gave a green light to the Russian separatists in Eastern Ukraine to initiate a new conflict situation. Obviously, Russia has been managing both the cases with its use of hard power. The Kremlin has been pressurizing in the Eastern Ukraine to distract attentions from Crimea. At the same time, Russia is demonstrating its power and assertiveness to the former Soviet countries to have them comply with the Russian policies in the region.

Russia has resorted to power, which not only is about using brute force but also creating pro-Russian forces and clandestinely supporting them, which is the case in both the situations. In Chechnya, the Kremlin has used its resources generously to create pro-Russian Chechen forces and eventually consolidated its power in Grozny through them. In Crimea, Russia used the local Russians to fulfill its political aspirations and to that end used vast resources. By using its power Russia likes to create no war, no peace situations in different regions that offer the Kremlin more leverage to reach its political objectives. The principles of national unity and territorial integrity are important to the Kremlin when they are needed for Russia. When it comes to others, it seems, Russia does not care much and violates those principles by using its hard power, which is a legacy of the Soviet Union.

\section{Bibliography:}

[1] Amirkhanov, R. (1998). The Tatar National Ideology, Anthropology \& Archeology of Eurasia 37, no. 2: 32-47;

[2] Askerov, A. (2011). Chechens From Past to Future: Healing the Wounds. Lambert Academic Publishing, GmbH \& Co. KG, Saarbrucken, Germany

[3] D'Anieri, P. J. (2010). Orange Revolution and Aftermath: Mobilization, Apathy, and the State in Ukraine. Washington, D. C: Woodrow Wilson Center Press. 
[4] Drobizheva, L. et al. (1998). Ethnic Conflict in The Post-Soviet World: Case Studies and Analysis. Armonk, N. Y: M. E. Sharpe.

[5] Gammer, M. (2006). The lone wolf and the bear: Three centuries of Chechen defiance of Russian rule. Pittsburgh: University of Pittsburgh Press.

[6] Gilligan, E. (2010). Terror in Chechnya: Russia and the tragedy of civilians in war. Princeton: Princeton University Press.

[7] Goble, P. (March 25, 2014). Crimean Tatars a Major Challenge to Moscow on Peninsula, Makarkin Says. The Interpreter. http: //www. interpretermag. com/crimean-tatars-a-major-challenge-to-moscow-on-peninsulamakarkin-says/ (Accessed October 21, 2014).

[8] Izmirli, I. P. (September 23, 2014). The Tale of the First Local Elections in Occupied Crimea and the End of Mejlis Era. Eurasia Daily Monitor, Vol. 11, Issue 167.

[9] Lalonde, S. (2002). Determining Boundaries in a Conflicted World: The Role of Uti Possidetis. Montréal, Quebec: McGill-Queen's University Press.

[10] Magocsi, P. R. (2014). This Blessed Land: Crimea and The Crimean Tatars. The University of Toronto Press.

[11] McWhinney, E. (2007). Self-determination of Peoples and Plural-ethnic States in Contemporary International Law: Failed States, Nation-building and the Alternative, Federal Option, BRILL.

[12] Nichols, J. (September 01, 2000). The Chechen Refugees. Berkeley Journal of International Law, 18, 2.

[13] Pastukhov, V. B. (2006). Ukraine is not with Russia: Causes and consequences of strategic miscalculations in Russia's policy toward Ukraine, Russian Politics \& Law, 44, no. 2, 39-54.

[14] Plokhy, S. (2006). The origins of the Slavic nations: Premodern identities in Russia, Ukraine, and Belarus. Cambridge, UK: Cambridge University Press.

[15] Schuerkens, U. (2012) Socioeconomic Outcomes of the Global Financial Crisis: Theoretical Discussion and Empirical Case Studies. New York: Routledge

[16] Seely, R. (2001). Russo-Chechen conflict, 1800-2000: A deadly embrace. Portland, OR: Frank Cass.

[17] Sheehy, A. and Nahaylo, B. (1980) The Crimean Tatars, Volga Germans and Meskhetians: Soviet Treatment of Some National Minorities. London: Minority Rights Group.

[18] Shevel, O. (2011). Russian Nation-Building from Yeltsin to Medvedev: Ethnic, Civic or Purposefully Ambiguous? Europe-Asia Studies. 63, no. 2 (2011): 179-202.

[19] Shevel, O. (March 1, 2014). Who are the Crimean Tatars, and Why are They Important? The Washington Post.

[20] Soldner, M. (2008). Political Capitalism and the Russian Media. In S. White (Ed. ), Media, Culture and Society in Putin's Russia (pp. 154-179). New York: Palgrave Macmillan.

[21] Toler, G. S. (2010). Chechnya Still Boiling. New York: Nova Science Publishers.

[22] Uehling, G. L. (2004). Beyond Memory: The Crimean Tatars' Deportation and Return. New York: Palgrave Macmillan.

[23] Ulrich, M. P. (2007). Ukraine's military between East and West. Carlisle Barracks, PA: Strategic Studies Institute, U. S. Army War College.

[24] Wilson, A. (2005). Ukraine's Orange Revolution. New Haven, Connecticut: Yale University Press 